\title{
BIOASSAY FOR INVESTIGATION OF AUXIN TRANSPORT IN SINGLE CELL LAYERS
}

\author{
ALINA B. WODZICKI, SYLWIA GESSEL AND TOMASZ J. WODZICKI \\ Department of Forest Botany, \\ Agricultural University of Warsaw (SGGW), \\ 26/30 Rakowiecka St., 02-528 Warsaw, Poland
}

(Received: March 3, 1997. Accepted: May 5, 1997)

\begin{abstract}
Auxin was collected from the cambial region of Pinus sylvestris by applying agar strips to the cut surfaces of stem sections which comprised a single layer of 2 to 4 - $\mathrm{mm}$ long, mainly intact fusiform cells. Sections of the agar strips were either bioassayed immediately to determine their auxin content or stored for several months at $-80^{\circ} \mathrm{C}$, extracted with $80 \% \mathrm{MeOH}$ and redissolved in hot agar prior to bioassay. Auxin concentrations were determined by Went's oat coleoptile test, as described by Funke, which was modified considerably to give highly reproducible results. The modifications proved essential for good replication of results and are described in detail together with the use of the bioassay to determine changes in cambial cell polarity during ageing and senescence in $P$. sylvestris.
\end{abstract}

KEY WORDS: bioassay, auxin, transport polarity, cambium, Pinus sylvestris.

\section{INTRODUCTION}

Polarity of auxin transport, associated in various ways with control of plant growth and development (Jacobs 1978; Hertel 1992), has usually been investigated in large multicellular systems of tissues or organs. The polarity of such multicellular structures arises at the level of single cells where it is also restituted after their successive divisions or gradually degraded with functional differentiation of the cell (Hertel 1992). Investigation of auxin transport through tissue structures with a limited number of cells and possibly a single cell layer is needed, especially in studies concerning the mechanism which integrates expression of the polarity of the component cells and contributes to the control of plant morphogenesis. This paper presents a method based upon the classic Avena coleoptile curvature test for auxin and allows the study of small sections of pine stem within which the cambial region is singlecelled in an axial direction. This method has not previously been described in detail but was used in earlier experiments on auxin transport in cambium (Wodzicki and Wodzicki 1973,1981 ; Wodzicki et al. 1979, 1984, 1987, 1988) and allowed detection of supracellular auxin waves assumed to represent a part of the system of morphogenetic information transfer and specification (Zajączkowski and Wodzicki 1978a, b; Wodzicki and Zajączkowski 1989).

\section{MATERIAL AND METHODS}

Stem blocks (20 × $20 \times 6 \mathrm{~cm})$ of adult (80-year-old) Pinus sylvestris L. trees were collected in the forest and recut in the laboratory to give smaller rectangular tissue segments with the following dimensions: $6 \mathrm{~mm}$ axially, $22 \mathrm{~mm}$ in a tangential direction to the stem circumference, and $2-3 \mathrm{~mm}$ in a radial direction (Fig. 1). These segments were composed of: 1) periderm from which the outer dead bark was removed, 2) the mature, maturing and non-functioning phloem, 3) meristematic cambial zone comprising cambial initials and the mother cells of phloem and xylem, 4) differentiating secondary $x y-$ lem, and 5) one to three recently deposited annual rings of wood. These stem sections were used either for investigation of auxin transport or, after further sectioning and staining, were studied by light microscopy combined with an Image Analyzer (WIKOM). For investigation of auxin transport, these 6-mm sections were used immediately after cutting from the larger stem blocks. Their length of $22 \mathrm{~mm}$ (parallel to the stem circumference) and thickness of 2-3 mm was suitable for application of agar strips $(20 \times 2 \times 2 \mathrm{~mm})$ used as the receivers or donors for auxin diffusing from or into the transversely cut tissues. The strips of $1 \%$ aqueous DIFCO bacteriological grade agar were applied at the apical or basal ends of the tissue sections opposite to the cambial zone and the differentiating tissues. After a predetermined period of diffusion the agar strips were detached and either cut into 10 cubes $(2 \times 2$ x $2 \mathrm{~mm}$ ) for bioassay (each cube was applied to a single oat coleoptile section) or the intact strips were lyophilized and stored at $-80^{\circ} \mathrm{C}$. The method of biological identification and quantitative measurement of the auxin diffused to agar was a modified version of the procedure of Funke (1939) based upon the oat coleoptile curvature test originally developed by Went (Went and Thimann 1937). These modifications (as described in the following pages) were critical for reducing the 


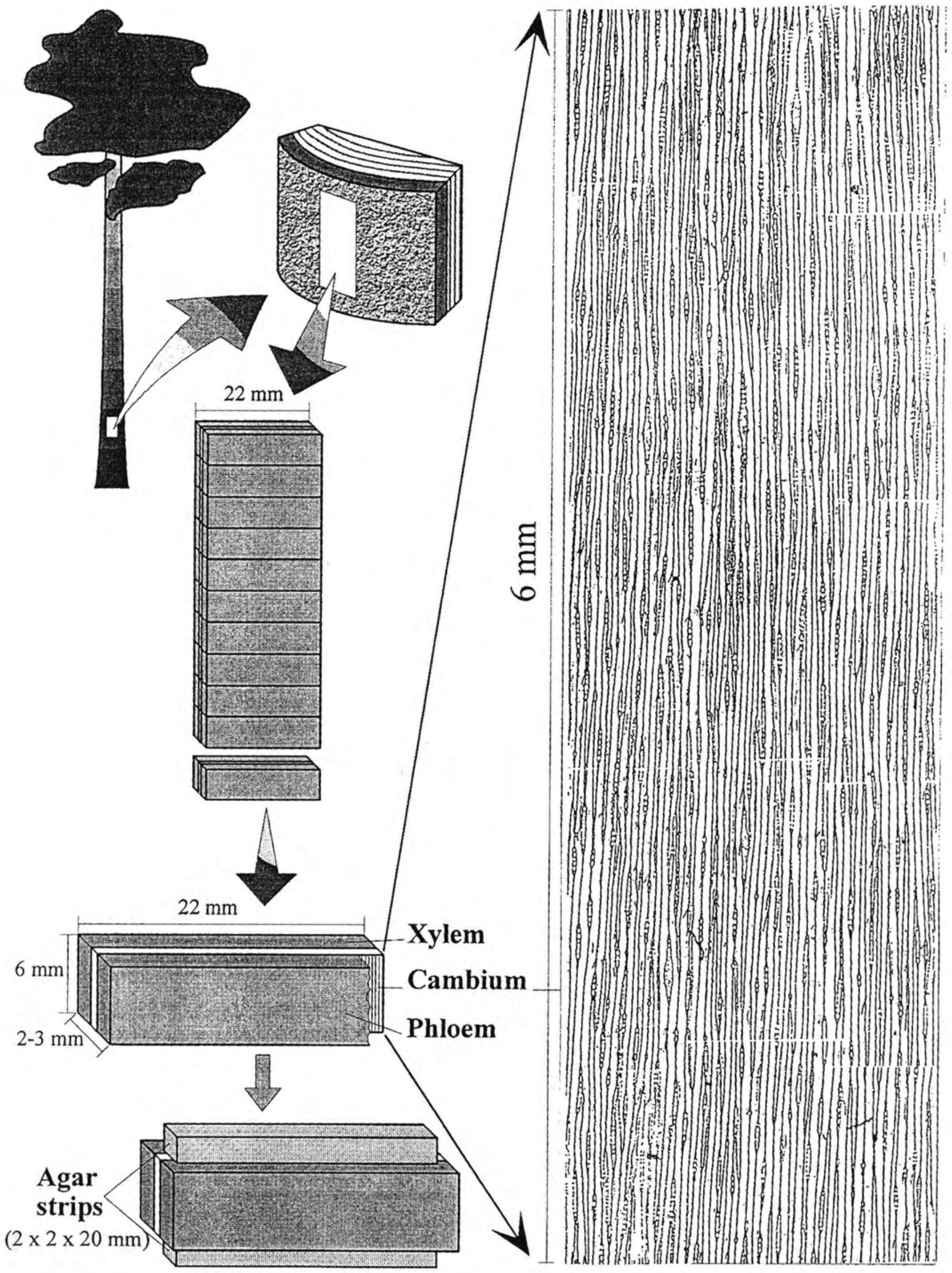

Fig. 1. Preparation of tangential sections of pine stem and collection of natural auxin by diffusion. 
variability of the method and rendered it highly reproducible for the quantitative determination of auxin.

\section{RESULTS}

\section{A. Organisation of fusiform cells in the cambial zone - ana- lysis of the tangential view of the section}

Cambial fusiform initials in $P$. sylvestris stem constitute a nonstoried structure of the axially-aligned meristematic cells. The length of these cells at chest height of the adult tree stem is on average $2.8 \pm 0.26 \mathrm{~mm}$. Eighty per cent of the cambial zone fusiform cells of the investigated stem sections (Fig. 1) fall within the length range $2-4 \mathrm{~mm}$ and there are no cells longer than $5 \mathrm{~mm}$. Analysis of the cellular pattern in the area of tangential stem sections 6-mm high (in an axial direction) and $22-\mathrm{mm}$ wide (along the stem circumference) was as follows:
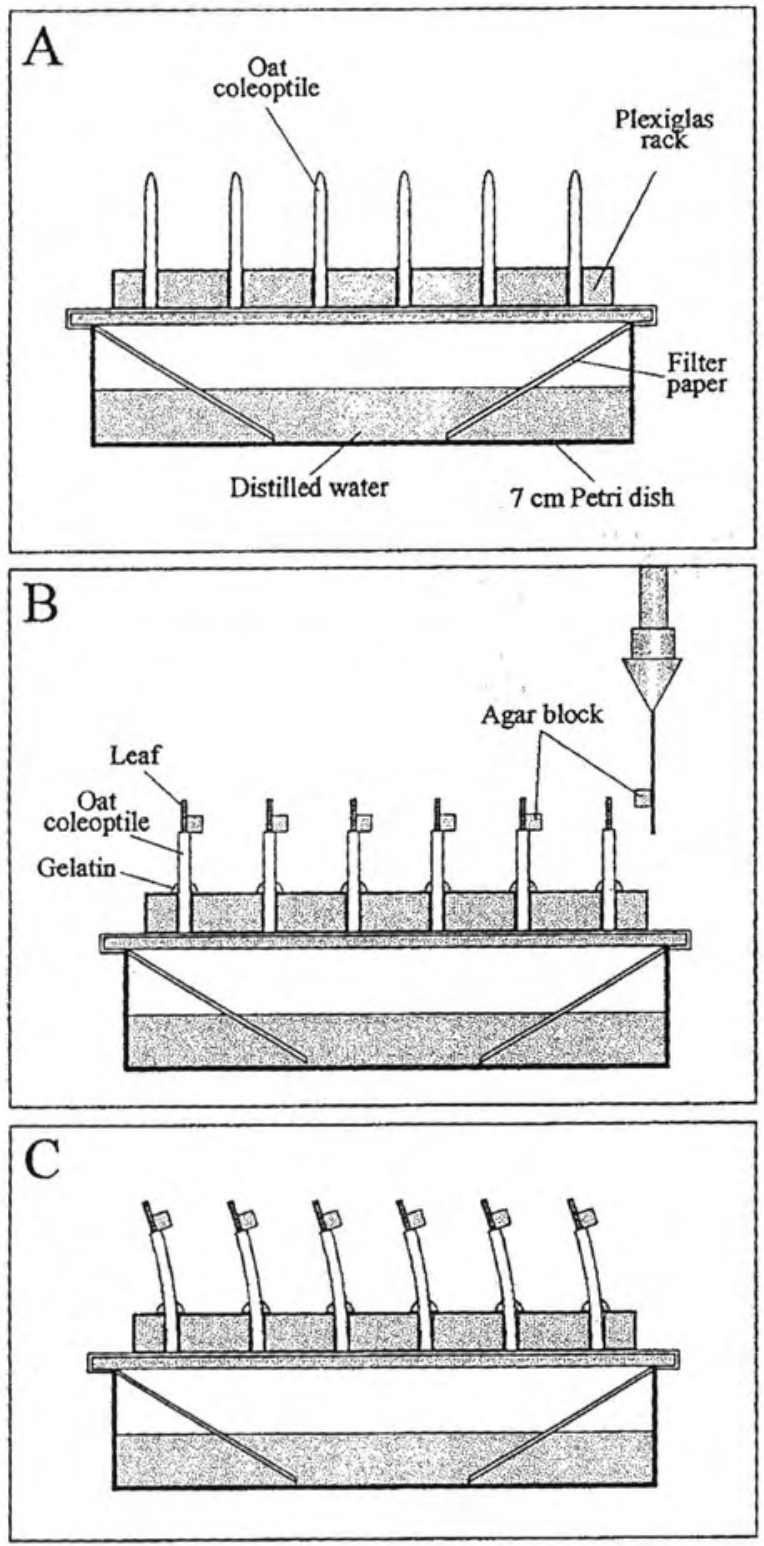

Fig. 2. Oat coleoptiles in the plexiglas rack, (A) on the day of harvest, (B) $20 \mathrm{~h}$ later after decapitation followed by setting the agar test blocks, and (C) after $19 \mathrm{~h}$ of incubation, when the growth response is measured.
1. There are 773 intact fusiform cells.

2. There are 642 fusiform cells cut transversely along each of the two (apical and basal) edges of the section.

3. The intact fusiform cells arranged only in a single axial row (the cells which have their both proximal and distal neighbours transversely sectioned) constitute 88.5 per cent of the whole population.

4. The intact fusiform cells arranged either in twos or threes in an axial direction (thus forming a single axial row) constitute 9.7 and 1.8 per cent respectively of the whole population.

5. There is no single row of cells in the cambial zone which if cut at both ends would provide an open channel allowing the transport of substances uncontrolled by the cytoplasm of the intact cells.

6. The fusiform cells are tightly cemented to each other by the middle lamella so there is no free space for other apoplastic transport except for the cell walls and the periplasmatic space probably controlled by the plasmalemma of each cell.

\section{B. The bioassay}

\section{a) Avena coleoptiles}

Uniform-sized healthy seeds of Avena sativa L. var. Seger II were selected from stock supplied by SVALÖF International, S-268 00 Svalöv, Sweden. No weighing is necessary but the number of seeds selected should be adequate to allow further selection of the coleoptiles. A 4 to 1 proportion of seeds sown to the number of coleoptiles needed for bioassay is satisfactory. The selected seeds are husked and soaked in distilled water for $2-3 \mathrm{~h}$ at $22-24^{\circ} \mathrm{C}$, usually in the darkroom. Effect of light is not critical at this stage. Plastic or wooden boxes $30 \times 40 \times 10 \mathrm{~cm}$ can be used for growing the coleoptiles. These are filled with moist clean sand to a depth of $5 \mathrm{~cm}$. The seeds should not be watered again before the coleoptiles are harvested, thus particular attention must be paid to ensure adequate moisture in the sand before sowing. Surplus water results in unequal germination and growth of the coleoptiles, causing the population to be unsuitable for the bioassay.

After pouring off the water in which they were soaked, the seeds are sown, oriented scutellum down, at a depth such that only the seed tip is visible. Seeds are sown at $1-\mathrm{cm}$ intervals and in rows $2 \mathrm{~cm}$ apart. The boxes are covered with glass plates and placed in a dark room at $22^{\circ} \mathrm{C}$ or in a well-aerated, thermostatically-controlled dark compartment. Without removing the glass plates the boxes with just-germinated seeds are exposed to two $1 \mathrm{~h}$ periods of red light, 51-52 $\mathrm{h}$ and 54-55 h after sowing. For this purpose two 10-watt fluorescent red tubes are positioned $50 \mathrm{~cm}$ above the boxes. Approximately 70 $72 \mathrm{~h}$ after sowing the oat coleoptiles are harvested by separating them from the seeds. The most suitable, and critical, length of the coleoptiles (the distance from node to intact tip) is $13 \pm 0.5 \mathrm{~mm}$; the mesocotyl length at this stage should be less than $1 \mathrm{~mm}$. Only straight coleoptiles of the proper length are harvested and positioned vertically with their bases in the holes made in $65 \times 20 \times 5$ mm Plexiglas rack-holders (Fig. 2). The harvest of oat seedlings and all later procedures are done under dim green-light illumination in a darkroom at $22^{\circ} \mathrm{C}$.

Approximately $20 \mathrm{~h}$ after harvest the coleoptiles are removed one by one and decapitated $2 \mathrm{~mm}$ below the tip using a special cutter made of 15 to $20 \mathrm{~cm}$-long forceps to the tips of which are fixed sections of razor blade edges (Fig. 3). On one arm of the forceps a screw prevents complete closure of the arms. By rotation of the screw the distance between the arms on closure of the forceps can be regulated to give a 1-mm gap 


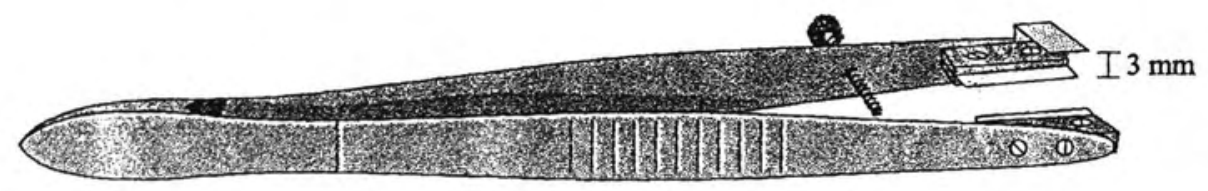

Fig. 3. The cutter, made of forceps and broken razor blade, used for decapitation of the oat coleoptiles. between the blades. This allows the tip of the coleoptile to be cut without damage to the first leaf within the coleoptile cylinder. The leaf is lifted up to break contact with the node and the leaf base positioned approximately $4 \mathrm{~mm}$ below the cut edge of the coleoptile. The upper part of the leaf is cut with scissors $5 \mathrm{~mm}$ above the upper edge of the coleoptile. Before the decapitated coleoptiles are returned to the rack a drop of hot pure gelatine is poured over each of the holes. This secures the bases of coleoptiles and maintains their vertical position at the start of the bioassay. It also prevents any bending other then that produced by the growth substances under test.

\section{b) The bioassay unit}

Ten to twelve coleoptiles set in one plexiglas rack are used as replicates to bioassay a sample of the test substances. The bioassay unit (Fig. 4) is secured in a glass housing and covered with tissue or filter paper as described below. Into the inverted cover of a 14-cm-diam. Petri dish lined with wet filter paper the bottom part of a 7-cm-diam. Petri dish is placed to serve as a support for the glass plate beneath the rack which holds the coleoptiles. The glass plate and the rack are separated by a strip of filter paper which dips into the bottom of the smaller Petri dish filled with $2 \mathrm{ml}$ of distilled water. The rack is covered with an inverted crystallization vessel (or low beaker) of 10-12 cm diameter and 7-cm high. A wet paper tissue is placed over the vessel to reach the bottom of the larger Petri dish. The bioassay units (equal to the number of test samples plus standards) are prepared before the coleoptiles are harvested and decapitated. They should not exceed 30-40 units for a single experiment.

\section{c. Incubation and measurements}

The bioassay units are incubated in a thermostatically-controlled environment in the dark at $26 \pm 0.5^{\circ} \mathrm{C}$ for $19 \pm 1 \mathrm{~h}$. Within this time limit the results do not differ significantly. For coleoptile measurements the bioassay units are removed individually in a sequence corresponding with the time schedule established for each of them at the start of incubation the day before.

Immediately after removal of the glass cover together with wet paper from the unit each of the coleoptiles is successively removed from the plastic rack to measure curvature. The measuring device is constructed of two transparent plastic (or thin plexiglas) plates (Fig. 5). A protractor scale drawn on paper is attached beneath the larger rectangular plate. In addition, straight lines are drawn parallel to a line connecting the $90^{\circ}$ point of the protractor scale with the central point of the base line (the line joining the points $0^{\circ}$ and $180^{\circ}$ ). A plastic ruler $25-\mathrm{mm}$ wide is attached with a small screw to the first plate at the central point of the base line of the protractor to function as a rotating arm. A straight line is drawn along the centre of this rotating arm parallel to the long edges.

The coleoptile to be measured is positioned at the bottom part of the rotating arm such that the straight lowermost part of the coleoptile overlays the median line of the movable arm

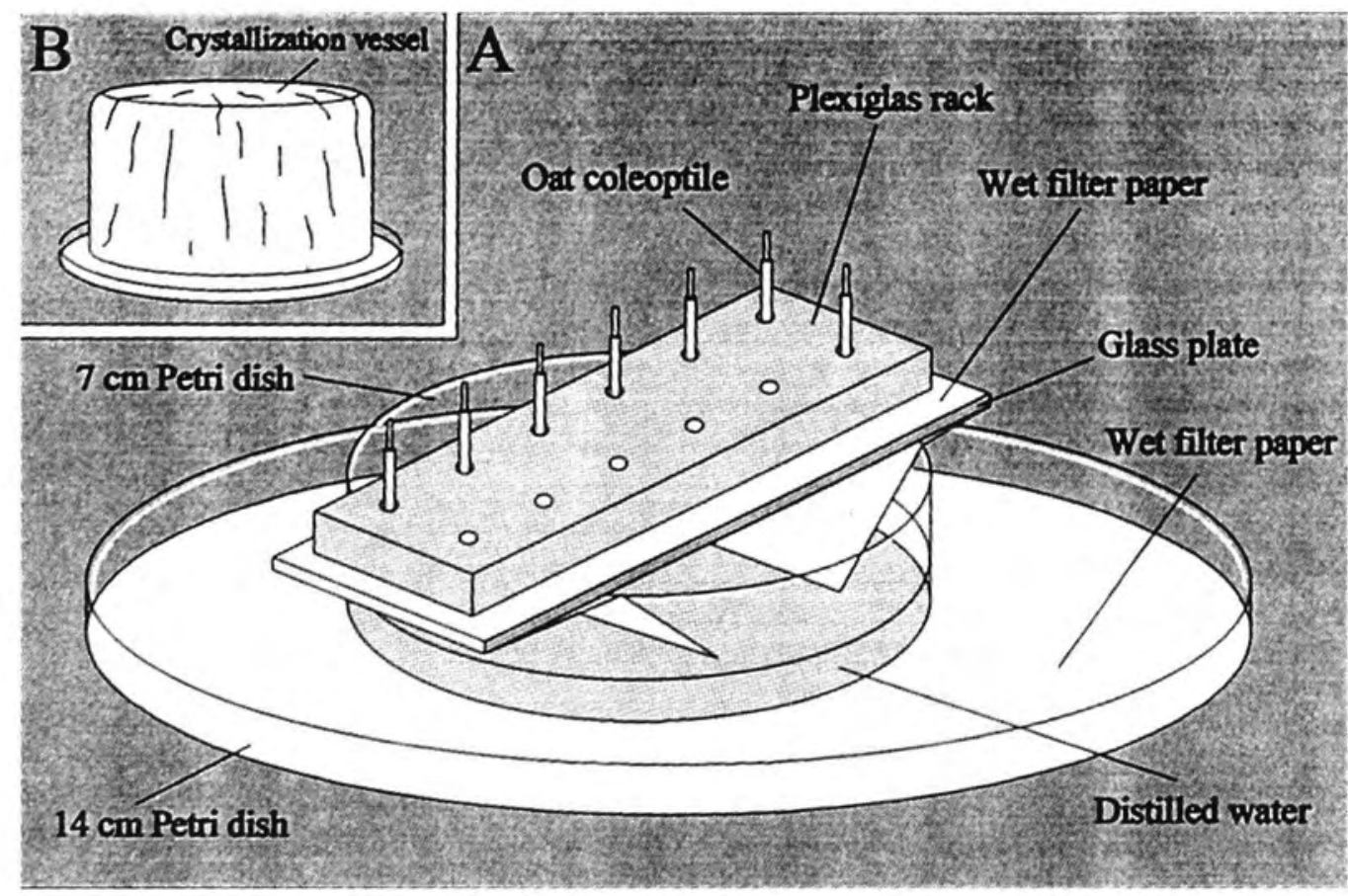

Fig. 4. Simplified view of the bioassay unit with the glass cover removed (A) and set for incubation (B). 
(Fig. 5A). A small drop of water improves adhesion of the coleoptile to the plastic during rotation of the arm to the point at which one of the vertical lines on the protractor becomes tangential to the arc of the curve at the cut end of the coleoptile (Fig. 5B). The line on the rotating arm points to the mark on the protractor scale which corresponds to the angle $(\alpha)$ to which the coleoptile bent.

\section{Responsiveness and Reproducibility \\ a) Synthetic IAA measurements}

Growth responses of oat coleoptiles to various concentrations of IAA applied in 8- $\mu \mathrm{l}$ agar cubes are presented in Fig. 6 . The data represent mean results of various numbers of tests performed in February and March 1991, and in February to July 1996, following the procedure described above. The lowest concentration of IAA at which a significant bending response is recorded and reproduced in successive tests is 0.005 $\mathrm{mg} \mathrm{l}^{-1}\left(2.85 \times 10^{-8} \mathrm{M}\right)$ or slightly less. This corresponds to about $30-40 \mathrm{pg}$ of auxin per cube of agar applied to each coleoptile. The semi-logarythmic relationship between the degree of curvature and IAA concentration is linear or nearly linear from 0.005 to $0.5 \mathrm{mg} \mathrm{l}^{-1}$ and parabolic for the range 0.005 to $5 \mathrm{mg} \mathrm{l}^{-1}$. The mean coleoptile curvatures within the most useful range of auxin concentration 0.005 to $1 \mathrm{mg} \mathrm{l}^{-1}$ are from 6.6 to 50.2 degrees.

The test results which are presented separately for two years (Table 1) were obtained with different seed stocks of $A$. sativa var. Seger II supplied by the same company in Sweden. Most of the bioassays were done by the same person (A.B.W.) but the results of some tests performed in 1996 by another person are included. The differences between the results were small but often statistically significant due to the low variability of the individual coleoptile responses within the bioassay units. The standard error of the mean of various tests measuring the same concentration of IAA usually does not exceed 3 percent. In the case of the lowest or highest concentrations tested, the standard error of the mean may reach 6 percent. The difference between the mean results of the bioassays at IAA conc. $0.01,0.05$ and $0.1 \mathrm{mg} \mathrm{l}^{-1}$ (carried out by two different persons and at various months over two years) did not exceed 3.5 degrees of curvature (1.5 to 2.0 degrees in the case of the same person). The statistically significant reso-

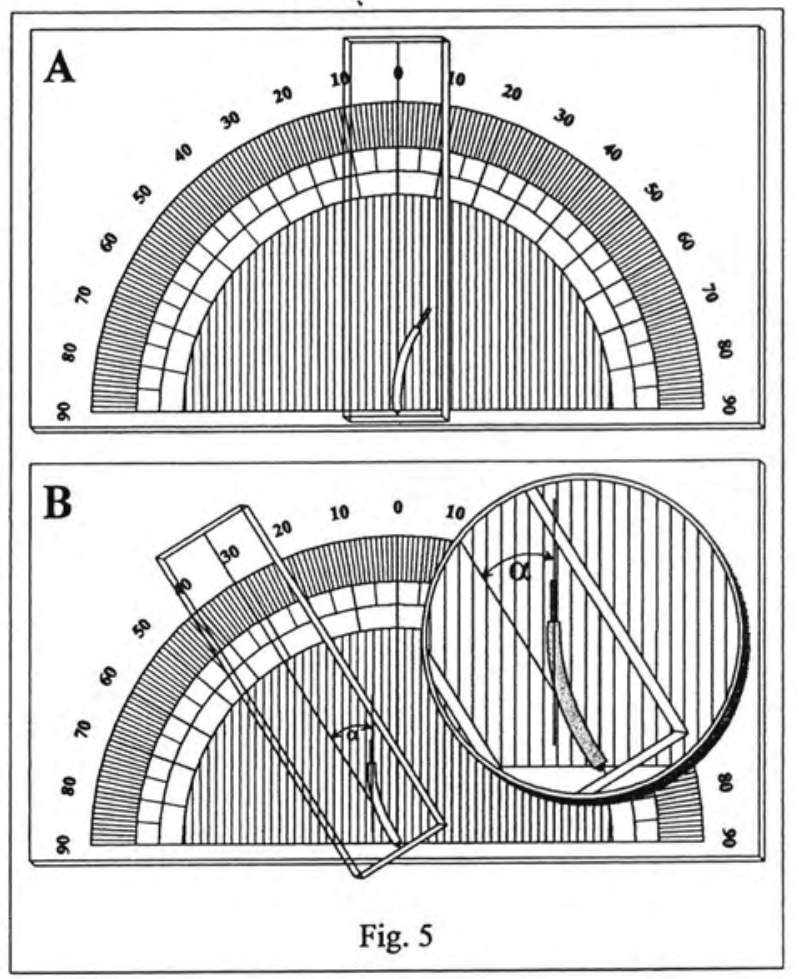

Fig. 5. Measurement of oat coleoptile curvature; steps A and B.

lution of the different sample measurements is around 2-3 degrees for the IAA concentration range $0.01-0.1 \mathrm{mg} \mathrm{l}^{-1}$ and $3-4$ degrees for the range of $0.1-1.0 \mathrm{mg} \mathrm{l}^{-1}$.

The growth response of the oat coleoptiles is very dependent upon the external conditions, especially the temperature at which the seedlings grow and the coleoptile sections are incubated. Nevertheless, the results of bioassays obtained in different laboratories by different people, as shown in the $0.1 \mathrm{mg} \mathrm{l}^{-1}$ IAA control measurements (Table 2), are remarkably close.

\section{b) Natural auxin of pine}

Cambial cell polarity changes associated with ageing and senescence in P. sylvestris (Wodzicki and Wodzicki, 1996)

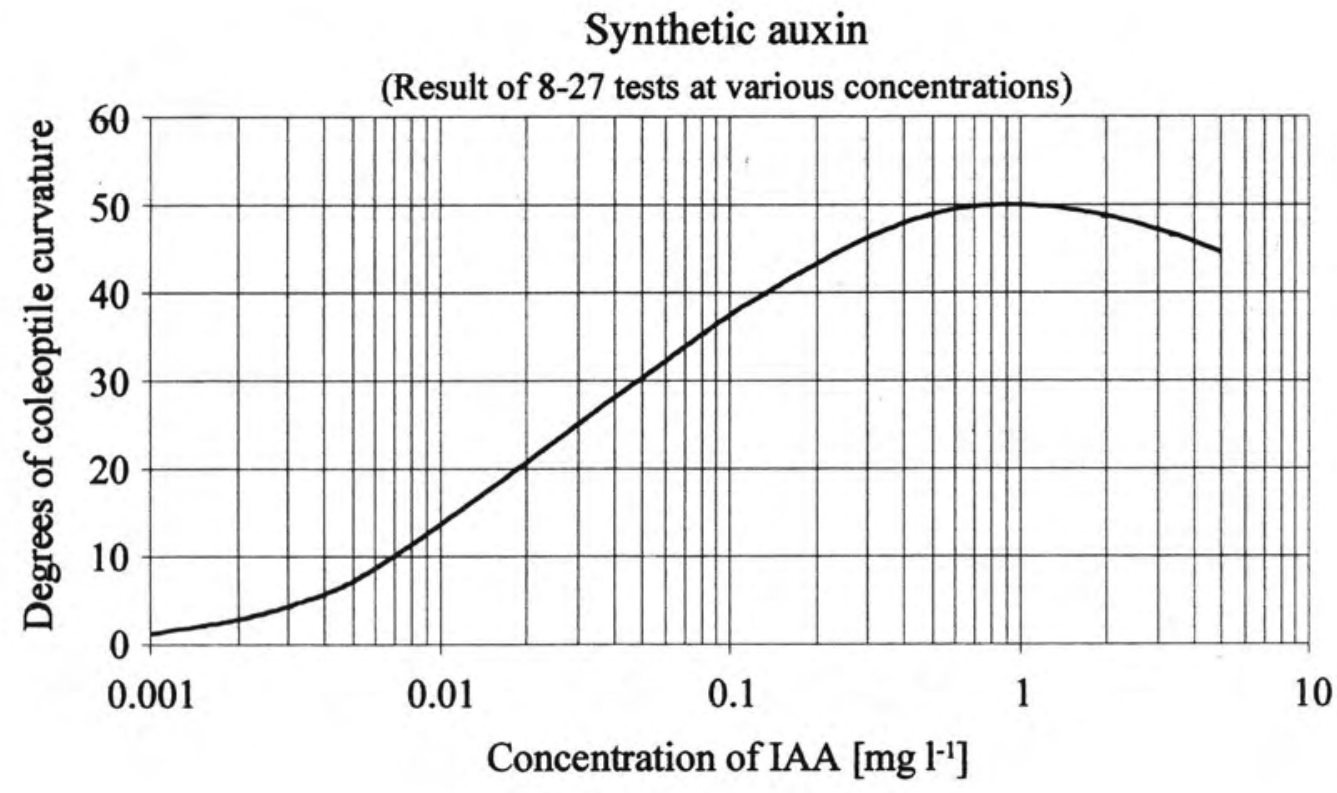

Fig. 6. Standard graph of coleoptile curvature to synthetic IAA. 
TABLE 1. Curvature of Avena sativa coleoptiles in response to indole-3-acetic acid measured with the bioassay described in this paper. Means presented in degrees of coleoptile curvature $(\alpha)$ with $( \pm)$ standard error (SE). All tests were done in the laboratory of the Forest Bot. Dept., Warsaw Agric. Univ., in 1991 (A) or 1996 (B, C) using different stocks of oat seeds. The tests specified under A and B were done by the same person i.e. the first author of this paper (A.B.W.), and by another person (C). Means refer to number of bioassay units (n) each of 10 coleoptiles. Usually 3 replicate bioassay units were processed in one day. If the mean is based on more then 3 units, the tests were performed at various dates of the years. The results are expressed graphically in Fig. 6.

\begin{tabular}{|c|c|c|c|c|c|c|c|c|c|c|c|c|c|c|}
\hline \multicolumn{2}{|c|}{$\begin{array}{c}\text { IAA } \\
\text { concentration }\end{array}$} & \multicolumn{3}{|c|}{ A } & \multicolumn{3}{|c|}{ B } & \multicolumn{3}{|c|}{$\mathrm{C}$} & \multicolumn{4}{|c|}{$\mathrm{A}, \mathrm{B}, \mathrm{C}$} \\
\hline $\mathrm{M}$ & $\mathrm{mg} 1^{-1}$ & $\mathrm{n}$ & $\alpha^{\circ}$ & SE & $\mathrm{n}$ & $\alpha^{\circ}$ & SE & $\mathrm{n}$ & $\alpha^{\circ}$ & SE & $\mathrm{n}$ & $\alpha^{\circ}$ & Degr. & $\%$ \\
\hline $5.70 \times 10^{-9}$ & 0.001 & - & - & - & 6 & 0.9 & 0.1 & 3 & 1.7 & 0.1 & 9 & 1.2 & 0.1 & 5.9 \\
\hline $2.85 \times 10^{-8}$ & 0.005 & 6 & 6.6 & 0.6 & 6 & 5.9 & 0.2 & 3 & 8.1 & 0.2 & 15 & 6.6 & 0.3 & 4.5 \\
\hline $5.70 \times 10^{-8}$ & 0.010 & 7 & 16.4 & 0.4 & 6 & 14.1 & 0.3 & 6 & 13.3 & 0.4 & 19 & 14.7 & 0.4 & 2.7 \\
\hline $2.86 \times 10^{-7}$ & 0.050 & 3 & 29.8 & 0.2 & 6 & 29.3 & 0.2 & 9 & 28.4 & 0.4 & 18 & 28.9 & 0.2 & 0.7 \\
\hline $5.70 \times 10^{-7}$ & 0.100 & 6 & 36.5 & 0.2 & 9 & 37.6 & 0.2 & 12 & 38.3 & 0.4 & 27 & 37.7 & 0.2 & 0.5 \\
\hline $2.85 \times 10^{-6}$ & 0.500 & 3 & 46.5 & 0.8 & - & - & - & 9 & 49.1 & 1.8 & 12 & 48.4 & 1.3 & 2.9 \\
\hline $5.70 \times 10^{-6}$ & 1.000 & 3 & 52.0 & 0.7 & 6 & 50.1 & 0.7 & 9 & 49.7 & 0.7 & 18 & 50.2 & 0.5 & 1.0 \\
\hline $2.85 \times 10^{-5}$ & 5.000 & 3 & 43.1 & 0.5 & - & - & - & 5 & 45.5 & 1.3 & 8 & 44.6 & 0.8 & 1.8 \\
\hline
\end{tabular}

TABLE 2. Results of bioassays done by A.B.W. and three other people in different laboratories using the same or different seed stocks of Avena sativa L. var. Seger II (indicated by the same or different letters). Warsaw - Dept. of Forest Botany, Univ. of Agric. Warsaw, Poland; Wageningen - Dept. of Plant Physiol., Univ. of Agric., Wageningen, Netherlands; Calgary - Dept. of Biology, Univ. of Calgary, Canada; Rogów - Expt. Forest Sta., Dept. of Forest Botany, Warsaw Agric. Univ. Rogów, Poland. Means and SE in degrees of coleoptile curvature. All results refer to 0.1 mg IAA $1^{-1}$. (J.A. - Jacek Adamczyk, E.K. - Ewa Kosel, K.M. - Katarzyna Marciszewska).

\begin{tabular}{|c|c|c|c|c|c|c|}
\hline \multirow[t]{2}{*}{ Date } & \multirow[t]{2}{*}{ Laboratory } & \multirow{2}{*}{$\begin{array}{c}\text { No. of } \\
\text { Bioassay units }\end{array}$} & \multicolumn{2}{|c|}{$\begin{array}{l}\text { Curvature of } \\
\text { the coleoptile }\left[\alpha^{\circ}\right]\end{array}$} & \multirow[t]{2}{*}{ Oat grain stock } & \multirow[t]{2}{*}{ Done by } \\
\hline & & & Mean & SE & & \\
\hline 1979 & Warsaw & 12 & 38.4 & \pm 0.3 & a & A.B.W. \\
\hline 1981 & Warsaw & 16 & 37.0 & \pm 0.3 & $\mathrm{~b}$ & A.B.W. \\
\hline 1982 & $\begin{array}{c}\text { Warsaw } \\
\text { Wageningen }\end{array}$ & $\begin{array}{l}6 \\
3\end{array}$ & $\begin{array}{l}38.1 \\
38.8\end{array}$ & $\begin{array}{l} \pm 0.4 \\
\pm 0.2\end{array}$ & $\begin{array}{l}\mathrm{b} \\
\mathrm{c}\end{array}$ & $\begin{array}{l}\text { A.B.W. } \\
\text { A.B.W. }\end{array}$ \\
\hline 1984 & $\begin{array}{l}\text { Warsaw } \\
\text { Calgary }\end{array}$ & $\begin{array}{c}5 \\
21\end{array}$ & $\begin{array}{l}38.0 \\
36.5\end{array}$ & $\begin{array}{l} \pm 0.3 \\
\pm 0.2\end{array}$ & $\begin{array}{l}\text { d } \\
\text { d }\end{array}$ & $\begin{array}{l}\text { A.B.W. } \\
\text { A.B.W. }\end{array}$ \\
\hline 1987 & $\begin{array}{l}\text { Warsaw } \\
\text { Rogów }\end{array}$ & $\begin{array}{c}5 \\
26\end{array}$ & $\begin{array}{l}37.3 \\
39.6\end{array}$ & $\begin{array}{l} \pm 0.3 \\
\pm 0.2\end{array}$ & $\begin{array}{l}\mathrm{e} \\
\mathrm{e}\end{array}$ & $\begin{array}{l}\text { A.B.W. } \\
\text { J.A. }\end{array}$ \\
\hline $1995-1996$ & Warsaw & $\begin{array}{l}4 \\
4 \\
4\end{array}$ & $\begin{array}{l}37.3 \\
37.8 \\
38.3\end{array}$ & $\begin{array}{l} \pm 0.3 \\
\pm 0.3 \\
\pm 0.4\end{array}$ & $\begin{array}{l}f \\
f \\
f\end{array}$ & $\begin{array}{l}\text { A.B.W. } \\
\text { K.M. } \\
\text { E.K. }\end{array}$ \\
\hline
\end{tabular}

were studied using the method described in this paper. The amounts of basipetal (B) and acropetal (A) efflux of natural auxin from the stem sections were measured simultaneously and the polarity of individual cells in the cambial region were calculated as the ratio $\mathrm{B} / \mathrm{A}$.

Stems of four dominant trees in each of the five age classes $(20,40,70,130$ and 180 years old) growing in a mixed pine forest were sampled at chest height. The cambial region stem sections of 6-mm height were used to measure amounts of natural auxin diffused during $15 \mathrm{~min}$ to the agar strips. The auxin of $P$. sylvestris had been identified earlier as indole-3acetic acid (Wodzicki 1968; Alden and Eliasson 1970; Sandberg et al. 1981; Wodzicki et al. 1987) so the bioassay results obtained in degrees of coleoptile curvature could be recalculated using standards of stimulation by synthetic IAA. Each result in Tables 3 and 4 corresponds to the auxin collected from the 3.33-mm long sector of tissues associated with the cambium along the stem circumference.
In this experiment the agar strips collected after the period of auxin diffusion were immediately frozen at the temperature of solid $\mathrm{CO}_{2}$ and transported to the laboratory where they were lyophilized and stored for $2-3$ months at $-80^{\circ} \mathrm{C}$. Directly before bioassay a series of 10 strips of agar collected from each tree were extracted 3 times with a total volume of $3 \mathrm{ml}$ of $80 \%$ methanol. The extracts were filtered, divided in equal volumes to five $10 \mathrm{ml}$ conical Pyrex centrifuge tubes and evaporated to dryness under vacuum. Each residue (equivalent to two agar strips or $40-\mathrm{mm}$ long sector of the stem cambial region) was dissolved (using a vortex shaker for 2-4 s) with 100 $\mu \mathrm{l}$ of $1 \%$ molten agar which was immediately pipetted as a single drop onto a $6 \times 8 \mathrm{~mm}$ piece of thick aluminium foil (Fig. 7). The foil plus hot agar was covered with another piece of foil of the same size to obtain an even spread of agar which was solidified in a refrigerator to form a plate approximately $2 \mathrm{~mm}$ thick. Then, after gentle removal of the upper aluminium foil, the agar plate was cut to twelve $8-\mathrm{mm}^{3}$ cubes, 
TABLE 3. Response of individual coleoptiles in each of the bioassay units testing the amounts of natural auxin in the 8- $\mu$ l agar cubes (each corresponding to a $3.33 \mathrm{~mm}$ segment of stem cambium) from the same sample for each of five pine trees differing by age. The data concern average basipetal or acropetal efflux of the pine auxin from ten successive 6-mm high stem sections for each tree sample as it was measured in one fifth the volume of the methanolic extract obtained from the ten original agar strips to which the auxin diffused from the cambial tissue. The residue of evaporated extracts was recovered into 100- $\mu$ l agar plates for bioassay. The data in picograms (which allowed calculation of the auxin transport polarity) refer to the standard curve of growth stimulation by synthetic IAA.

\begin{tabular}{|c|c|c|c|c|c|c|c|c|c|c|}
\hline \multirow{3}{*}{$\begin{array}{l}\text { Coleoptile } \\
\text { number }\end{array}$} & \multicolumn{5}{|c|}{ Degrees of Avena coleoptile curvature } & \multicolumn{5}{|c|}{ Auxin [picograms] } \\
\hline & \multicolumn{10}{|c|}{ Tree age [years] } \\
\hline & 20 & 40 & 70 & 130 & 180 & 20 & 40 & 70 & 130 & 180 \\
\hline \multicolumn{11}{|c|}{ Basipetal transport (B) } \\
\hline 1 & 37 & 39 & 36 & 30 & 30 & 784 & 956 & 710 & 391 & 391 \\
\hline 2 & 40 & 37 & 36 & 28 & 30 & 1056 & 784 & 710 & 321 & 391 \\
\hline 3 & 42 & 43 & 32 & 27 & 28 & 1288 & 1422 & 477 & 291 & 321 \\
\hline 4 & 43 & 36 & 30 & 29 & 29 & 1422 & 710 & 391 & 354 & 354 \\
\hline 5 & 40 & 39 & 31 & 30 & 30 & 1056 & 956 & 432 & 391 & 391 \\
\hline 6 & 37 & 38 & 34 & 33 & 31 & 784 & 866 & 582 & 527 & 432 \\
\hline 7 & 38 & 40 & 33 & 28 & 30 & 866 & 1056 & 527 & 321 & 391 \\
\hline 8 & 40 & 35 & 29 & 27 & 28 & 1056 & 643 & 354 & 291 & 321 \\
\hline 9 & 36 & 34 & 34 & 29 & 29 & 710 & 582 & 582 & 354 & 354 \\
\hline 10 & 36 & 36 & 35 & 30 & 29 & 956 & 710 & 643 & 391 & 354 \\
\hline Mean & 39.2 & 37.7 & 33.0 & 29.1 & 29.4 & 998 & 869 & 541 & 363 & 370 \\
\hline SE & 0.71 & 0.84 & 0.77 & 0.57 & 0.31 & 72.1 & 78.0 & 40.0 & 22.0 & 11.2 \\
\hline
\end{tabular}

\begin{tabular}{|c|c|c|c|c|c|c|c|c|c|c|}
\hline \multicolumn{11}{|c|}{ Acropetal transport (A) } \\
\hline 1 & 20 & 21 & 17 & 24 & 18 & 150 & 166 & 111 & 223 & 123 \\
\hline 2 & 20 & 17 & 18 & 24 & 16 & 150 & 111 & 123 & 223 & 101 \\
\hline 3 & 19 & 20 & 17 & 20 & 18 & 136 & 150 & 111 & 150 & 123 \\
\hline 4 & 19 & 16 & 20 & 18 & 20 & 136 & 101 & 150 & 123 & 150 \\
\hline 5 & 20 & 24 & 17 & 17 & 19 & 150 & 223 & 111 & 111 & 136 \\
\hline 6 & 23 & 18 & 16 & 21 & 18 & 202 & 123 & 101 & 166 & 123 \\
\hline 7 & 24 & 17 & 16 & 19 & 17 & 223 & 111 & 101 & 136 & 111 \\
\hline 8 & 24 & 16 & 18 & 19 & 17 & 223 & 101 & 123 & 136 & 111 \\
\hline 9 & 25 & 17 & 16 & 20 & 17 & 247 & 111 & 101 & 150 & 111 \\
\hline 10 & 22 & 19 & 19 & 20 & 18 & 183 & 136 & 136 & 150 & 123 \\
\hline Mean & 21.6 & 18.5 & 17.4 & 20.2 & 17.8 & 180 & 133 & 117 & 157 & 121 \\
\hline SE & 0.72 & 0.81 & 0.43 & 0.73 & 0.36 & 13.1 & 12.1 & 5.2 & 12.1 & 4.4 \\
\hline \multicolumn{11}{|c|}{ Polarity (B/A) } \\
\hline Mean & 1.8 & 2.1 & 1.9 & 1.5 & 1.7 & 6 & 7 & 5 & 2 & 3 \\
\hline SE & 0.09 & 0.07 & 0.07 & 0.06 & 0.04 & 0.8 & 0.5 & 0.4 & 0.2 & 0.1 \\
\hline
\end{tabular}

ten of which were used in a single bioassay unit of ten coleoptiles.

The bioassays of the natural auxin efflux (or diffusate) from the stem cambial region of one of the four pine trees simultaneously tested in each of the tree age classes are presented in Table 3 to illustrate the degree of confidence in the method. The analysis of variance, which includes all four trees in each age class (Table 4), shows a significant effect of ageing on auxin transport polarity in the stem cambial region of pine. This is in spite of only four trees being tested in each age class and each tree with only a single bioassay unit of 10 coleoptiles (Wodzicki and Wodzicki 1996).

The agar cubes for testing can be obtained (and usually are) by simple sectioning of the original agar strips immediately after the diffusion from plant tissues is completed. This method is possible only if the sectioning of the plant tissue (the stem cambial region in this case) and the diffusion of auxin to agar is accomplished in the laboratory ready for immediate bioassay, as was done in earlier experiments (Wodzicki and Wodzicki, 1973; Wodzicki et al., 1979, 1984, 1988; Adamczyk and Wodzicki, 1987). On the other hand, the method of extraction of the diffusates from agar strips described here allows combination of the bioassays with purification, identification and quantification of the natural auxin by standard analytical procedures such as high performance liquid chromatography with a fluorimetric detector (HPLC) (Wodzicki et al., 1990; Wodzicki and Wodzicki, 1996) and/or gas-chromatography-mass spectrometry-selected ion monitoring (GC-MS SIM) (Wodzicki et al., 1987). Testing the pine auxin after it has been recovered from the lyophilized agar strips used in this experiment provides the possibility of working with a greater number of samples after several months storage, thus permitting larger experiments which require simultaneous collection of material. 


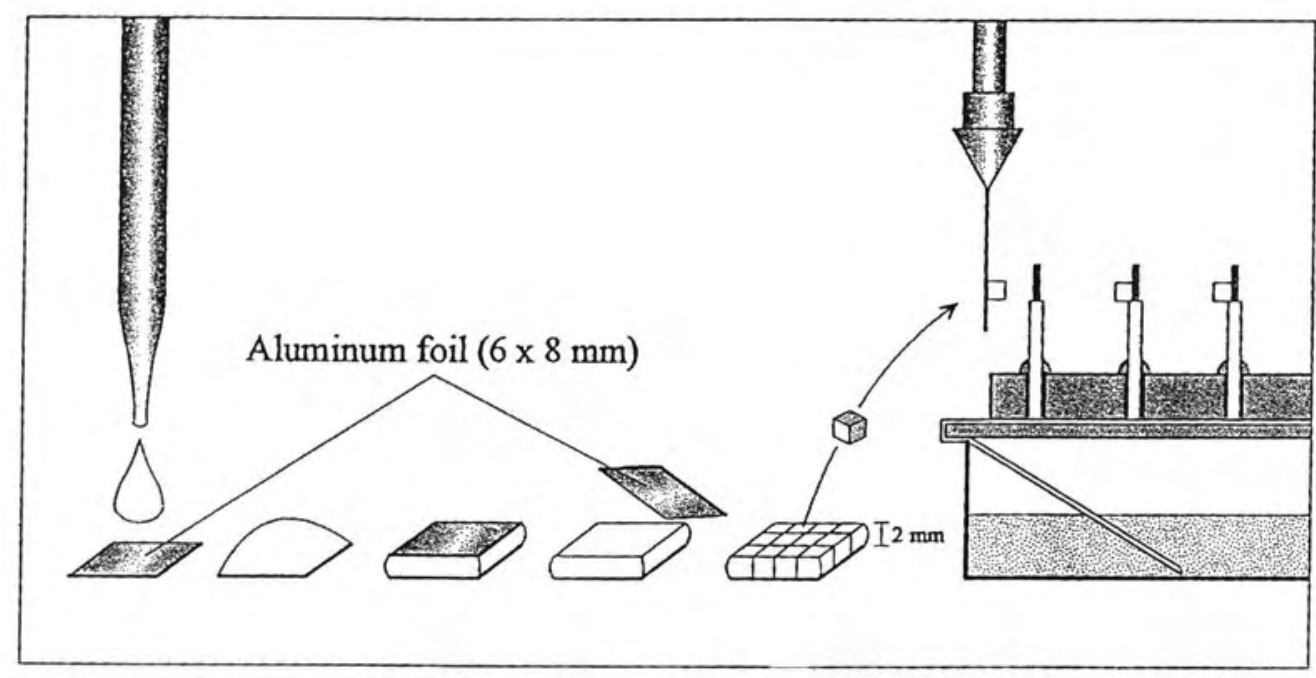

Fig. 7. Formation of twelve $8-\mu \mathrm{l}$ cubes of agar for bioassay from a $100-\mu \mathrm{l}$ drop of hot agar.

TABLE 4. Significance of testing the natural auxin basipetal (B) or acropetal (A) efflux from the stem cambial region of pine, and the polarity of this transport calculated as the ratio B/A or as B-A. The data refer to mean results obtained from separate bioassays of the auxin collections from four different trees in each age group of the trees. Natural auxin amounts relate to $3.33 \mathrm{~mm}$ segments of the cambium along the stem circumference or 107 tangentially successive radial series of the cambial fusiform derivatives. The analysis of variance and least significant difference (LSD) were calculated after the results of bioassays had been converted to picograms, using stimulation by synthetic IAA as standards.

\begin{tabular}{|c|c|c|c|c|c|c|c|}
\hline \multirow{2}{*}{\multicolumn{3}{|c|}{ Auxin efflux }} & \multicolumn{5}{|c|}{ Tree age [years] } \\
\hline & & & \multirow{2}{*}{$\begin{array}{c}\mathbf{2 0} \\
531\end{array}$} & \multirow{2}{*}{$\begin{array}{r}40 \\
464\end{array}$} & \multirow{2}{*}{$\begin{array}{c}70 \\
425\end{array}$} & \multirow{2}{*}{$\begin{array}{l}130 \\
324\end{array}$} & \multirow{2}{*}{$\begin{array}{l}180 \\
301\end{array}$} \\
\hline & & Mean [pg] & & & & & \\
\hline & & $\begin{array}{l}\text { LSD } \alpha=0.01 \\
\text { LSD } \alpha=0.05\end{array}$ & \multicolumn{5}{|c|}{$\begin{array}{l}109.57 \\
83.37\end{array}$} \\
\hline \multirow{2}{*}{\multicolumn{2}{|c|}{ Acropetal }} & Mean [pg] & 152 & 145 & 151 & 133 & 130 \\
\hline & & $\begin{array}{l}\text { LSD } \alpha=0.01 \\
\text { LSD } \alpha=0.05\end{array}$ & \multicolumn{5}{|c|}{$\begin{array}{l}33.95 \\
25.83\end{array}$} \\
\hline \multirow{4}{*}{$\begin{array}{l}\text { Polarity } \\
\text { of auxin } \\
\text { transport }\end{array}$} & \multirow[t]{2}{*}{$\mathbf{B} / \mathbf{A}$} & Mean & 3.36 & 3.43 & 2.99 & 2.49 & 2.32 \\
\hline & & $\begin{array}{l}\text { LSD } \alpha=0.01 \\
\text { LSD } \alpha=0.05\end{array}$ & \multicolumn{5}{|c|}{$\begin{array}{l}0.77 \\
0.59\end{array}$} \\
\hline & \multirow[t]{2}{*}{ B-A } & Mean & 378.9 & 319.2 & 274.3 & 191.6 & 171.8 \\
\hline & & $\begin{array}{l}\text { LSD } \alpha=0.01 \\
\text { LSD } \alpha=0.05\end{array}$ & \multicolumn{5}{|c|}{$\begin{array}{l}81.33 \\
61.88\end{array}$} \\
\hline
\end{tabular}

\section{DISCUSSION}

Why revive the classic bioassay for auxin measurement when modern analytical methods are available? The A. sativa coleoptile curvature test, developed first by Went as described by Went and Thimann 1937) and modified by Funke (1939), appears to be not only quite selective but also the fastest method, very convenient if direct measurements of the diffusible auxin from many samples are needed simultaneously. Nevertheless, to obtain a satisfactory level of reproducibility and resolution of measurements several modifications of Funke's procedure were found necessary as described in this paper. These concerned: 1) the time of red-light induction of the germinating oat seeds which should be given as two 1-h periods starting on 52 and $54 \mathrm{~h}$ after sowing and growth in complete darkness (there is always variability in the time of germination of the oat seeds and red light arrests mesocotyl elonga- tion in a greater number of seedlings at the same, very early stage of growth), 2) the times of harvest and decapitation of the coleoptiles must be separated by a period of approx. 20$22 \mathrm{~h}$; they should be 70-72 and $90 \mathrm{~h}$ respectively after sowing (the time of harvest should be when the coleoptile length is $13 \pm 0.5 \mathrm{~mm}$ from the node), 3) the temperatures during germination, coleoptile growth and decapitation must be kept exactly at $22^{\circ} \mathrm{C}$, and $26^{\circ} \mathrm{C}$ during incubation of the coleoptile sections with the agar test blocks, 4) the relative humidity must be kept at 100 per cent during all stages of the bioassay but care should be taken not to overwater the oat seeds (the seedlings should not be watered during growth). An obvious condition of success is that all the manual actions described in the particular sections of this paper are performed accurately. The only fully reliable stock of seeds of the desired oat variety (according to our knowledge) is that obtained from the indicated company in Sweden. 
Although the techniques described require a skill which needs more practice than is usually needed with the use of analytical techniques, this effort is rewarded with specific advantages in the investigation of auxin action. The high sensitivity and low variability of the coleoptile responses make possible a high level of resolution of measurements, especially when very small amounts of natural auxin have to be determined simultaneously in as many as 30-40 samples and in several replicate tests. This could hardly be obtained with any of the known analytical methods (Wodzicki et al. 1987). The method described allows direct investigation of growth response processes such as: 1) the interaction of growth or metabolic inhibitors with the mechanism of auxin control of stem elongation and polarity expression (Wodzicki and Wodzicki 1994), 2) the auxin transport throughout the known sector of the plant organ, and even across a single axial row of cells, 3 ) the spatial and temporal oscillations of the tissue polarity expression can be traced, thus it may be the most convenient method for investigation of auxin waves, 4) the transduction of auxin signaling (or inductive) effects upon the systems controlled by natural auxin transport (Wodzicki 1993; Wodzicki and Wodzicki 1994). The method is the fastest of available techniques for natural auxin measurements if the bioassay is carried out with agar cubes from agar strips collected immediately after contact with plant tissue for a few minutes. The low cost of bioassays as compared with known analytical methods makes the procedures described here a very convenient and economic tool for natural auxin investigation, especially if the biological tests are occasionally backed up by specific analytical methods.

Measuring the difference between the amounts of the natural auxin efflux simultaneously from apical and basal ends of small pine stem sections comprising only a single axial row of fusiform cells in the meristematic region of cambium provides a unique opportunity of studying the expression of plant cell polarity and integration of the supracellular systems in respect to the developmental processes associated with polar transport of auxin. As described above, the direct bioassay of auxin efflux in agar appears especially useful in such studies, however, a few comments concerning some aspects of the method and possibilities of increasing its efficiency merit further discussion. First, even though the tangential number of cambial fusiform cells can be counted along the stem sector circumference used for collection of auxin, the results of auxin efflux measurements cannot be entirely attributed to these cells because the structural complexity of the stem cambial region suggests contribution of other cells of the cambial zone. Each of the cambial initials (or the majority of them) produce by periclinal divisions radial rows of immature fusiform elements of the stem conducting system, secondary phloem and xylem. These differentiating cells are still meristematic in the cambial zone but soon enlarge and differentiate to form the dead cellular conducting elements of secondary xylem or the enucleated phloem sieve tubes. The 2-mm-wide agar strip applied opposite the stem cambial region collects by diffusion the substances from all these cellular components of the tissue. Nix and Wodzicki (1974) provided evidence that auxin transport is restricted mostly to the meristematic cambial zone. However, radial cell number in this zone alters with change in environmental or developmental conditions, (e.g. during the season) thus anatomical studies may be very helpful in the final interpretation of the results of auxin transport measurements, especially at the cellular level.

If the period of contact of the agar with stem tissue is short enough the accumulation of various substances by simple dif- fusion is much less than the auxin collection which is enhanced by active transport. Nevertheless, the interference of nonauxin substances diffused to agar may be a problem especially if these are synergistic agents to the growth response of oat coleoptiles to auxin. Less problems come from interaction of growth inhibitors because their action in this bioassay is expressed only when auxin is present in the tested sample (otherwise the coleoptile does not grow, even without inhibitors). Most problems of this type can be solved by including controls containing both IAA and the inhibitor or by allowing efflux of natural auxin (together with the native inhibitor) to agar receiver strips containing known concentrations of synthetic auxin. Occasional verification of the bioassay results with standard analytical methods is desirable.

The cell length in the stem cambial region of various tree species is different and varies with the age of the stem or branch. While the fusiform cambial zone cell of adult pines, larches and spruces may be similar, the cambial cells of maples, ashes and oaks are several times shorter (e.g. $0.350 \mathrm{~mm}$ in Fraxinus excelsior L.), or longer as in Sequoia sempervirens $\mathrm{L}$. (5-9 $\mathrm{mm}$ according to Bailey 1923). If the polarity of auxin transport is investigated at this level of tissue organisation the length of stem sections must be adjusted to a size which allows only a single axial row of intact cambial cells. This is approximately twice the mean length of the fusiform initial in nonstoried cambia. On the other hand, wider stem sections may be used to investigate co-operation of several of the cambial cell axial layers in the expression of stem polarity.

If stem section length is selected properly there should not be any free space within the tissue sector used for investigation of auxin transport which would provide a canal for the uncontrolled flow of auxin. Some natural canals, e.g. resin ducts, cannot be avoided. Fortunately the axial components of such exudation systems rarely occur in the cambial zone and those present in the neighbouring maturing or mature tissues are already filled with resins or gum which is concentrated at the cut ends of the canal, so preventing easy penetration of this route for auxin transport. Still, if any leak of the auxin occurred this way there probably would be no preferable direction of translocation, thus an equal contribution to both acropetal and basipetal movement would be expected. Finally, one has to remember that when transport of natural auxin is measured the agar strips as receivers are set at the edges of the stem section where practically all cells in direct contact with agar are cut transversely. Thus, what diffuses first to agar are substances flowing out with the vacuolar sap and fragments of membranes or organelles. This component of the cell diffusate accumulates probably in equivalent amounts at both ends of the stem section. Its effects determined in the bioassay can be subtracted, or not, from the results obtained for measurement of the basipetal efflux which obviously contains the component of the active transport. This may sometimes be important for interpretation of the expression of stem polarity because under these circumstances the real acropetal transport of auxin from the intact cells cannot be precisely determined.

\section{ACKNOWLEDGEMENT}

The authors wish to thank Dr. Peter M. Robinson for critical reading of the paper before submission to the journal, and to Dr. J. Adamczyk for his very helpful co-operation in processing the tables and figures. 


\section{LITERATURE CITED}

ADAMCZYK J. AND WODZICKI T.J. 1987. Acropetal effects of IAA upon the wavelike pattern in the basipetal efflux of natural growth substances of Fraxinus excelsior L. Acta. Soc. Bot. Pol. 56: 407413.

ALDEN T.L. AND ELIASSON L. 1970. Occurrence of indole-3-acetic acid in buds of Pinus sylvestris. Physiol. Plant. 23: 145-153.

BAILEY I.W. 1923. The cambium and its derivative tissues. IV. The increase in girth of the cambium. Amer. J. Bot. 10: 499-509.

FUNKE H. 1939. Über den nachweiss kleines Wuchsstoffmengen. Jahrb. Wiss. Bot. 88: 375-378.

HERTEL R. 1992. Transport and action of auxin are closely related. In (Proc. 8th FESPP Congr. Antwerp.) Session: Signal transduction mechanisms.

JACOBS W.P. 1978. Regulation of development by the differential polarity of various hormones as well as by effects of one hormone on the polarity of another. In Regulation of developmental processes in plants (ed. H R Scutte and D. Gross), pp. 361-380. Jena: VEB Gustaw Fisher Verlag.

NIX L.E. AND WODZICKI T.J. 1974. The radial distribution and metabolism of IAA-14C in Pinus echinata stems in relation to wood formation. Can. J. Bot. 52: 1349-1355.

SANDBERG G., ANDERSON B. AND DUNBERG A. 1981. Identification of 3-indole-acetic acid in Pinus silvestris L. by gas-chromatography-mass spectrometry, and quantitative analysis by ion-pair reversed-phase liquid chromatography with spectrofluorimetric detection. J. Chromatography. 205: 125-137.

WENT F.W. AND THIMANN K.V. 1937. Phytohormones. New York: McMillan.

WODZICKI T.J. 1968. On the question of occurrence of indole-3-acetic acid in Pinus silvestris L. Am. J. Bot. 55: 564-571.

WODZICKI T.J. 1993. Auxin apical control of the auxin polar transport and its oscillation - a suggested cellular transduction mechanism. Acta Soc. Bot. Pol. 62: 37-41.

WODZICKI T.J. AND WODZICKI A.B. 1973. Auxin stimulation of cambial activity in Pinus silvestris L. II. Dependence upon basipetal transport. Physiol. Plant. 29: 288-292.

WODZICKI T.J. AND WODZICKI A.B. 1981. Modulation of the oscillatory system involved in polar transport of auxin by other phytohormones. Physiol. Plant. 53: 176-180.
WODZICKI T.J. AND WODZICKI A.B. 1994. Auxin apical control of the auxin polar transport in stem cambium of Pinus silvestris L. Biologia Plantarum 36 (suppl.): 57.

WODZICKI T.J. AND WODZICKI A.B. 1996. Auxin transport polarity changes in the stem cambial region of Pinus silvestris L. associated with ageing. In Biodiversity protection of Białowieża primeval forest. (ed. P. Paschalis and S. Zajączkowski), pp. 23-34. Warsaw.

WODZICKI T.J. AND ZAJACZKOWSKI S. 1989. Auxin waves in cambium and morphogenetic information in plants. In (Proc. 14th Bioch. Cong. Prague Coll.) Signals in plant development (ed. J. Krekule and F. Seidlova), pp. 45-64.

WODZICKI T.J., WODZICKI A.B. AND ZAJĄCZKOWSKI S. 1979. Hormonal modulation of the oscillatory system involved in polar transport of auxin. Physiol Plant. 46: 97-100

WODZICKI T.J., KNEGT E., WODZICKI A.B., BRUINSMA J. 1984. Is indolyl-3-acetic acid involved in the wavelike pattern of auxin efflux from Pinus silvestris stem segments? Physiol. Plant 61: 209213.

WODZICKI T.J., ABE H., WODZICKI A.B., PHARIS R.P. AND COHEN J.D. 1987. Investigation on the nature of auxin-wave in the cambial region of pine stems. Validation of IAA as the auxin component by the Avena coleoptile curvature assay and by gas-chromatography-mass spectrometry-selected ion monitoring. Plant Physiol. 84: 135-143.

WODZICKI T.J., WODZICKI A.B AND BROWN C.L. 1988. Oscillation of stem polarity expression in transport of natural auxin of pine cambium. Acta Soc. Bot. Pol. 57: 165-176.

WODZICKI T.J., WODZICKI A.B., RAKOWSKI K. AND ZAKRZEWSKI J. 1990. Natural auxin mobility in stem cambial region of $P i$ nus silvestris L. under conditions of soil pollution with sulphuric acid and urea. Folia Forestalia Pol. Seria A - Forestry. 32: 49-93.

ZAJACZKOWSKI S. AND WODZICKI T.J. 1978a. On the question of stem polarity with respect to auxin transport. Physiol. Plant. 44: 122-126.

ZAJĄCZKOWSKI S. AND WODZICKI T.J. 1978b. Auxin and plant morphogenesis - A model of regulation. Acta Soc. Bot. Pol. 47: 233-243.

\section{TEST BIOLOGICZNY DO BADANIA TRANSPORTU AUKSYNY W POJEDYNCZYCH WARSTWACH KOMÓREK}

\section{STRESZCZENIE}

Naturalną auksynę zbierano z rejonu kambialnego Pinus sylvestris L. przez przykładanie pasków agaru do powierzchni przecięcia wycinków pnia, które zawierały jedną warstwę przeważnie nieprzeciętych wrzecionowatych komórek o długości od 2 do $4 \mathrm{~mm}$. Odcinki pasków agarowych były badane testem biologicznym na zawartość auksyny albo bezpośrednio po zbiorze, albo po dłuższym okresie przechowywania w temperaturze $-80 \mathrm{C}$, wyekstrahowaniu $80 \% \mathrm{MeOH}$, i powtórnym zatopieniu ekstraktu w agarze. Do oznaczeń stężeń auksyny zastosowano test koleoptile owsa Wenta w wersji opisanej przez Funke, który został jednak istotnie zmodyfikowany, co pozwoliło osiągnąć wysoce powtarzalne wyniki pomiaru. Modyfikacje, o których mowa okazały się tak dalece ważne dla powtarzalności wyników, że zostały szczegółowo opisane w tym artykule wraz z przykładem zastosowania testu w szerszych badaniach zmian polarności komórek kambialnych w okresie starzenia się drzew Pinus sylvestris.

SŁOWA KLUCZOWE: test biologiczny, auksyna, transport polarny, kambium, Pinus sylvestris. 